\section{CIF Awards}

\section{Jacques Fernand Couturier}

Mr. Couturier, a native of Edmunston, New Brunswick has been selected as the recipient of the Schlich Memorial Prize. Mr. Couturier is a graduate of the Forest Engineering program at the University of New Brunswick where he consistently placed amongst the top students in his class. He won a New Brunswick Design Council Award in 1974 and also was selected as one of the four UNB representatives for the 1977 Festival of Forestry Tour.

Mr. Couturier's interests include swimming, jogging, snowshoeing and weight lifting as well as active participation in student affairs where he served on the executive committee for the Forest Engineering Student Association.

Mr. Couturier is working with the Woodlands Division of J. D. Irving Ltd.

\section{Paul Christopher Ward}

Mr. Paul Christopher Ward, the winner of the 1977 Canadian Institute of Forestry Medal at the University of Toronto, is the son of Mr. and Mrs. Lee R. Ward of Hamilton, Ontario.

Mr. Ward entered the Faculty of Forestry and Landscape Architecture in September of 1973 and graduated with the degree of Bachelor of Science in Forestry (B.Sc.F.) in June of 1977. He maintained first class honours standing throughout his four undergraduate years and has been the recipient of several awards including the Ontario Professional Foresters Association Prize and the Canadian Institute of Forestry Medal in his graduating year. He has been active in extra-curricular affairs as a student representative on staff-student committees and in his final year served as President of the Forester's Club.

Mr. Ward is presently employed with the Forest Fire Control Branch of the Ontario Ministry of Natural Resources.

\section{Keith Christopher Jones}

Keith Christopher Jones is the University of New Brunswick winner of the Canadian Institute of Forestry Medal for 1977. He maintained enviably high standing during his three academic years of coursework, and first-class ratings by his summerwork supervisors in both the Forest Management Institute and the National Research Council.

'K.C.' completed public and high school in Ottawa, and a Bachelor of Engineering (Electrical) degree from Carleton University in 1973, before registering in Forest Engineering at UNB. He was awarded the BScFE degree with first-division standing at Encaenia, 19 May 1977.

At the end of the academic year, Mr. Jones returned to Ottawa to resume work at NRC.
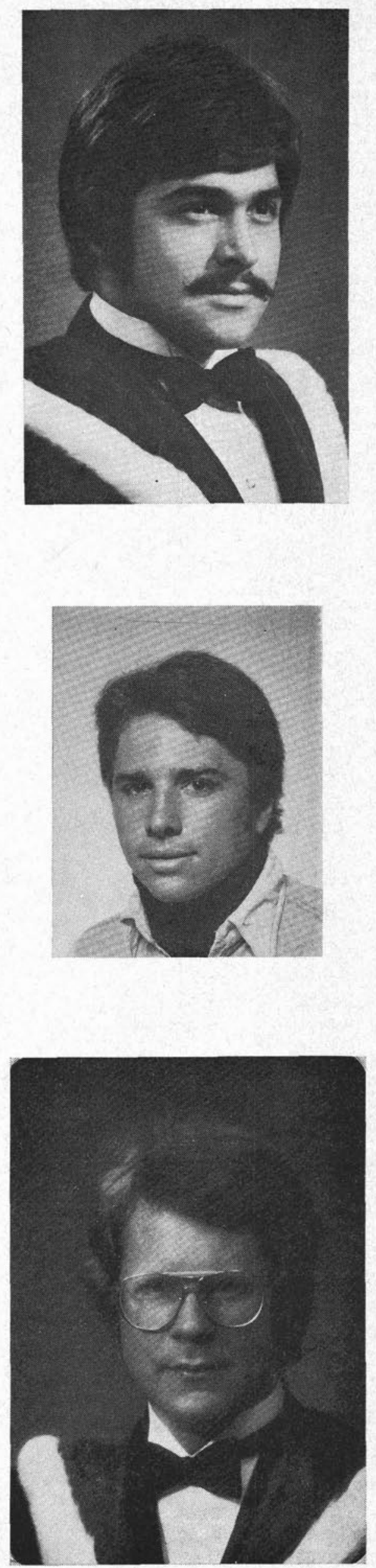


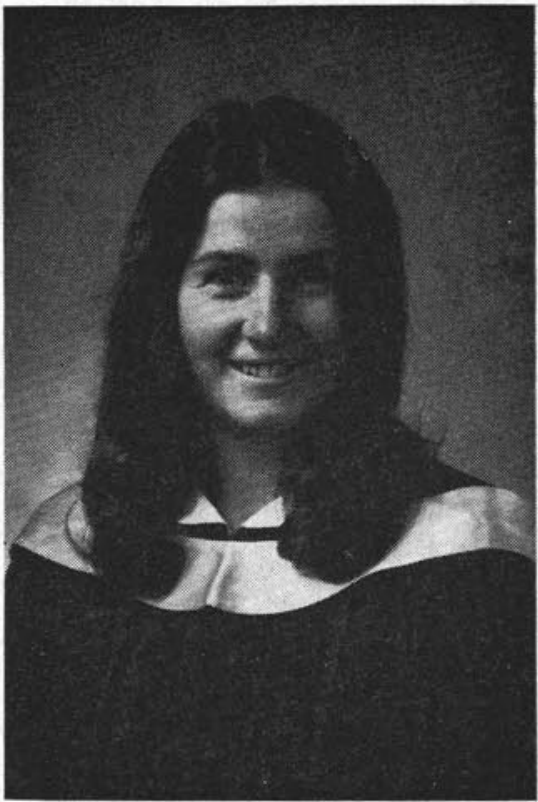

\section{Mary Elizabeth Suttie}

Miss Suttie was born in Kamloops, B.C. on December 9, 1954, and later moved to Merritt where she obtained her elementary and secondary education. In 1972-73 Miss Suttie entered the Faculty of Science at UBC where she obtained a first class standing. In virtually all of the courses Miss Suttie took after transferring to the Faculty of Forestry in 1973-74, up to and including her fourth year of Forestry, Miss Suttie has maintained a first class standing. She has indeed shown an exemplary performance throughout her period of studies at UBC.

Miss Suttie's outstanding academic performance has been acknowledged by the Faculty of Forestry during the period of her attendance at this Faculty beginning with The Truck Loggers' Association Scholarship in her first year and culminating with the honour of being awarded both the H. R. MacMillan Prize in Forestry, which is awarded to the student who has the highest standing in fourth year forestry, and the Canadian Institute of Forestry Medal for 1977. She was a member of the Curriculum Committee of the Faculty of Forestry and Junior Handbook Chairman during her fourth year, as well. Her hobbies include cross-country skiing and hiking.

Summer jobs of Miss Suttie have included two summers with Fraser Mills of Quesnel, B.C. and one summer with the Research Division of the B. C. Forest Service at Williams Lake. Presently Miss Suttie is employed by West Fraser Mills as Reforestation Forester.

\section{Margarete Julie Hee}

The 1977 Canadian Institute of Forestry Medal,

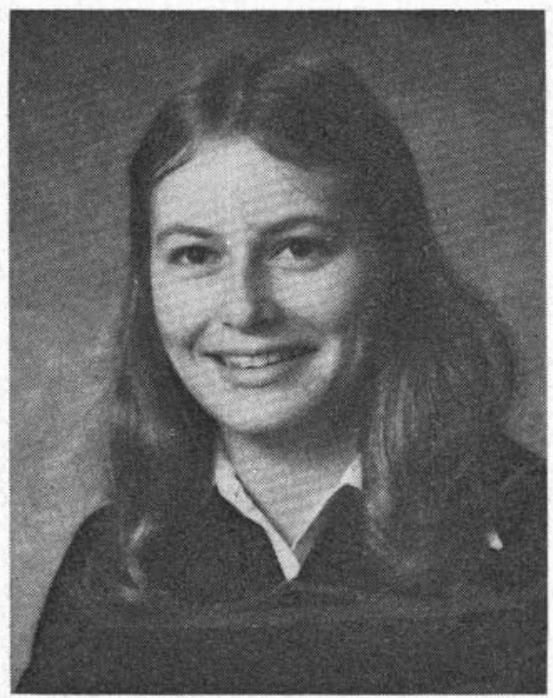
for the University of Alberta was awarded to Ms. Margaret Julie Hee at the Rocky Mountain's June meeting at Kanaskas Experimental forest. Margarete earned an exceptional academic record maintaining first class standing every year of her program. During the summers she has worked for a) the Alberta Forest Service as a compassman (her words), cruiser, planting crew supervisor, and Junior Forest Ranger leader, b) the Canadian Forest Service on a remote sensing project; c) the University of Alberta as a spring camp teaching assistant; and d) several Swedish concerns in Sweden as an exchange student. Work in Sweden included planting, thinning, and river driving.

During the year in addition to her studies she was very active in the student Forest Society and served as a teaching assistant in several forestry courses. Margarete's achievement, prior to graduation were recognized by her receipt of a Douglas Farquhar Johnston Bursary, an Alberta Forest Service Scholarship, a Board of Governers Prize in Agriculture and forestry and three Province of Alberta Undergraduate Scholarships.

After this summers work with the Alberta Forest Service, Margarete plans to travel to New Zealand. Her long term career interest is industrial forest management. 